\title{
Phencyclidine (PCP)-like discriminative stimulus effects of metaphit and of 2-amino-5-phosphonovalerate in pigeons: generality across different training doses of PCP
}

\author{
W. Koek ${ }^{1}$, J.H. Woods ${ }^{1,2}$, A.E. Jacobson ${ }^{3}$, and K.C. Rice ${ }^{3}$ \\ ${ }^{1}$ Department of Pharmacology and ${ }^{2}$ Department of Psychology, M6322 Medical Science Buılding I, University of Michıgan, \\ Ann Arbor, MI, USA \\ ${ }^{3}$ Laboratory of Chemistry, NIADDKD, National Institutes of Health, Bethesda, MD, USA
}

\begin{abstract}
Pigeons were trained to discriminate either a fixed dose of PCP $(1 \mathrm{mg} / \mathrm{kg} ; n=3)$ or a progressively decreasing dose $(1-0.56-0.32 \mathrm{mg} / \mathrm{kg} ; n=4)$ from saline. Lowering of the training dose shifted the dose-effect curve for PCP's discriminative stimulus effects about 5 -fold to the left, in a parallel manner, but did not decrease the accuracy of the discrimination performance and did not significantly increase the extent to which pentobarbital and chlordiazepoxide produced PCP-appropriate responding. Dose-effect curves based on binary generalization data were evaluated statistically with new methods that may be more appropriate than those used previously. Metaphit, a proposed PCP-receptor acylator, and 2-amino-5-phosphonovalerate (AP5), an N-methyl-D-aspartate (NMDA) antagonist, produced complete PCP-appropriate responding in the high training dose group only at doses that suppressed the rate of responding and that produced ataxia. However, 4-fold lower doses of metaphit and AP5, which did not produce directly observable behavioral effects, were found to substitute completely for PCP in the low training dose group. These data support the notion that PCP, metaphit, and AP5 have a common discriminative effect in pigeons.
\end{abstract}

Key words: Drug discrimination - Training dose - Pharmacological specificity - Threshold dose analysis - Phencyclidine - Excitatory amino acids - Receptor acylator - 2-Amino-5-phosphonovalerate (AP5) - Metaphit - Pentobarbital - Chlordiazepoxide - Pigeons

Phencyclidine (PCP), a significant drug of abuse, has anticonvulsant effects (e.g., Chen et al. 1959), analgesic and anesthetic effects (e.g., Chen and Weston 1960), effects that resemble schizophrenia (e.g., Domino and Luby 1981), and anticonflict effects (e.g., Cook and Davidson 1973). Certain of these effects might result from a PCP receptor-mediated reduction of neurotransmission at excitatory synapses utilizing NMDA-preferring receptors (i.e., AA1 receptors; Fagg et al. 1986). Recently, we reported behavioral evidence in support of this hypothesis: 2-amino-5-phosphonovalerate (AP5), a potent and highly selective NMDA antagonist (Watkins and Evans 1981), produced PCP-like behavioral effects in pigeons and in rats (Koek et al. 1986a, b, 1987),

Offprint requests to: W. Koek, FONDAX - Groupe de Recherche SERVIER, 7 Rue Ampere. F-92800 Puteaux, France and may produce PCP-like behavioral effects in rhesus monkeys (Woods et al. 1986). However, the results of our study in pigeons (Koek et al. 1986 b) suggested an important difference between AP5 and PCP: AP5 may produce PCP-like discriminative stimulus effects only at doses that greatly increase the key-selection latency and are very close to the cataleptic dose, unlike PCP.

Metaphit, a derivative of PCP differing by the metaphenyl substitution of an isothiocyanate group, specifically acylates PCP receptors in vitro (Rafferty et al. 1985) and in vivo (Contreras et al. 1986). Metaphit produced PCP-like stereotyped behavior and ataxia in some rats, leading Contreras et al. (1986) to conclude that metaphit is a weak PCP agonist. In pigeons and in rhesus monkeys, metaphit produced PCP-like agonist actions (Koek et al. 1985, 1986c). However, metaphit induced PCP-like discriminative stimulus effects in pigeons only at doses that greatly increased the key-selection latency and that were very close to the cataleptic dose, unlike PCP.

Thus, PCP-like discriminative stimulus effects of AP5 and metaphit were observed only at doses that also produced other behavioural effects (i.e., ataxia and greatly increased latencies to select the PCP-appropriate key). The first aim of the present experiment was to characterize further the PCP-like discriminative stimulus of AP5 and metaphit: first, by studying the ability of these compounds to substitute for a training dose of PCP that was lowered progressively from 1 to $0.32 \mathrm{mg} / \mathrm{kg}$, and second, by comparing the results directly to data that were obtained previously with these compounds in pigeons in which $1 \mathrm{mg} / \mathrm{kg} \mathrm{PCP}$ was used throughout as the traninig dose. In pigeons, discriminative stimulus control that is induced by $1 \mathrm{mg} / \mathrm{kg}$ PCP is characterized by a high degree of accuracy and pharmacological specificity (e.g., Herling et al. 1981; McMillan 1982; Leander 1982). However, it has been suggested that the pharmacological specificity of a drug discrimination may be codetermined by the training dose (e.g., Colpaert et al. 1980). In particular, a lowering of the training dose may result in reduced pharmacological specificity and broadened stimulus generalization (i.e., "overinclusiveness", Overton 1974). Thus, a second objective of the present study was to investigate possible differences in the pharmacological specificity of the discriminative stimulus properties of different training doses of PCP.

In drug discrimination, response selection is one of the currently used variables to measure discrimination and generalization. In a drug-saline discrimination, response selec- 
tion is a binary variable, i.e., selection of the saline response or selection of the drug response. When different doses are tested of a treatment that produces drug-appropriate responding, the percentage of animals selecting the drug response can be plotted as a function of dose in log-linear coordinates. Analysis of these data by means of the method of Litchfield and Wilcoxon (1949) is not entirely appropriate, as the data samples at different doses are obtained in the same subjects and are therefore not independent (Stolerman and D'Mello 1981). Appropriate methods for statistical analysis of these dose-effect curves for related samples do not seem to be available (Colpaert 1986). A third objective of the present study was to explore a different approach to this problem, by using methods in which the lowest dose that produces selection of the drug response (i.e., threshold dose) was used as the basic datum for statistical analysis.

\section{Materials and methods}

Subjects. Eight experimentally naive White Carneaux pigeons (Palmetto, Sumter, SC) were housed individually with water and grit freely available and were maintained at $80 \%$ of their free-feeding weight by providing mixed grain in the home cage after each experimental session.

Apparatus. Six ventilated, sound-attenuated chambers measuring $36 \times 28 \times 33 \mathrm{~cm}$ were used. Three translucent response keys, $2.4 \mathrm{~cm}$ in diameter, were located on the inside of one wall, $25 \mathrm{~cm}$ from the chamber floor. The keys were $5 \mathrm{~cm}$ from each other and could be transilluminated by red $7 \mathrm{~W}$ lights located behind the wall. Mixed grain was made available for reinforcement by means of a hopper, below the center response key and $10 \mathrm{~cm}$ above the floor of the chamber. A Texas Instruments Inc. (Dallas, TX) $960 \mathrm{~A}$ computer, located in an adjacent room, was used for programming and data collection.

Procedure. After autoshaping of a key-peck response, all pigeons were trained to discriminate an IM injection of $1 \mathrm{mg} / \mathrm{kg}$ PCP from saline. Training sessions were conducted 7 days/week. Each session was preceded by an injection of either PCP or saline, after which the pigeon was placed in the experimental chamber. After $10 \mathrm{~min}$, during which the chamber was dark and key-peck responses had no programmed consequences, the houselight came on and the left and the right key were illuminated red. During the first two to three sessions saline was administered and responses on the right key resulted in 4-s access to mixed grain, according to a reinforcement schedule that was gradually changed from fixed ratio (FR) 1 to FR 20. The key lights were off during food presentation and a white light illuminated the hopper. A session ended after 50 reinforcements, or after $1 \mathrm{~h}$, whichever occurred first. During the next two to three sessions PCP was administered, responses on the left key were reinforced and the reinforcement schedule was changed from FR 1 to FR 20. Thereafter, drug and saline sessions alternated according to a double-alternation sequence. Twenty responses on the injection-appropriate key (i.e., left key PCP-appropriate, right key saline-appropriate) resulted in reinforcement. Responses on the inappropriate key had no programmed consequences. Training was continued until less than five responses were made on the injection-inappropriate key, before the first food presentation, during ten consecutive sessions. When this training criterion was met, test sessions (T) and drug (D) and saline (S) training sessions were conducted according to two, weekly alternating, sequences: S-D-T-S-T-D-T, D-S-T-S-T-D-T. A test session ended, without reinforcement, when 20 responses had been made on either key, or after $1 \mathrm{~h}$, whichever occurred first. The key on which 20 responses accumulated first was defined as the selected key.

Tests were conducted only if the injection-appropriate key was selected during both the immediately preceding drug training session and saline training session, otherwise drug and saline training sessions were alternated until the appropriate key was selected during two consecutive sessions.

Different doses of PCP were tested in all eight pigeons. Thereafter, the training dose of PCP was decreased from 1 to $0.56 \mathrm{mg} / \mathrm{kg}$, in five pigeons. After these pigeons met the discrimination criterion at the lowered training dose, different doses of PCP were tested and the training dose was reduced further to $0.32 \mathrm{mg} / \mathrm{kg}$. Both the pigeons that met the discrimination criterion when $0.32 \mathrm{mg} / \mathrm{kg}$ PCP was used as the training dose $(n=4)$ and the pigeons for which the training dose remained at $1 \mathrm{mg} / \mathrm{kg}(n=3)$, were tested with PCP, metaphit, AP5, pentobarbital and chlordiazepoxide. The injection-test interval was $1 \mathrm{~h}$ for metaphit, $30 \mathrm{~min}$ for AP5 and $10 \mathrm{~min}$ for the other drugs.

Data analysis. The percentage of PCP-key selections was used as a measure of PCP-like discriminative stimulus effects. The lowest dose that produced selection of the PCP key (generalization threshold dose) was determined for each subject, for each drug. The geometric mean threshold dose was used as a measure of the drug's potency. Drug potencies can best be compared if the dose effect curves are parallel. The slope of the curve relating log-dose with percentage of PCP-key selections is a function of the variance of the log-threshold doses; as this variance increases, the slope becomes less steep. Thus, parallelism of dose-effect curves may be evaluated by testing for homogeneity of the variances of the log-threshold doses. However, tests for homogeneity of variance may not have a high degree of sensitivity (e.g., Winer 1971). Therefore, a different approach was taken to evaluate parallelism of dose-effect curves: a line was fitted by linear regression to log dose-effect data for each drug and the statistical significance of slope differences was assessed, using the methods described by Tallarida and Murray (1981).

Selection latency was defined as the time between the illumination of the response keys and the occurrence of key selection. Selection latencies were log-transformed prior to statistical analysis.

Data were analyzed by one-factor repeated measures ANOVA and by two-factor ANOVA with repeated measures on one factor (Winer 1971). Post-hoc comparisons were made using Dunnett's $t$-test. A likelihood ratio Chisquare test (Everitt 1977) was used to analyze effects of different training doses on the maximum percentage of PCP-key selections produced by drugs that failed to induce $100 \%$ PCP-key selection. For each drug, a $2 \times 2$ contingency table was constructed with the following cell entries: maximum number of pigeons, trained with $1 \mathrm{mg} / \mathrm{kg} P C P$, that selected the PCP key; remaining number of similarly trained pigeons that selected the saline key; maximum number of pigeons, trained with $0.32 \mathrm{mg} / \mathrm{kg} \mathrm{PCP}$, that selected the PCP key; remaining number of similarly trained 
pigeons that selected the saline key. The degree of heterogeneity in each contingency table was calculated by means of likelihood ratio Chi-square (see Robbins 1977 for a worked example).

Drugs. The compounds used were phencyclidine hydrochloride (Warner-Lambert/Parke-Davis and Co., Ann Arbor, MI), metaphit (1-[1-(3-isothiocyanatophenyl)cyclohexyl]piperidine) methanesulphonate (provided by Dr. A.E. Jacobson and Dr. K.C. Rice, National Institutes of Health, Bethesda, MD), DL-2-amino-5-phosphonovalerate (AP5) hydrochloride (Sigma Chemical Co., St. Louis, MO), pentobarbital sodium (Gaines Chemical Works, New York, NY) and chlordiazepoxide hydrochloride (Hoffmann-La Roche, Nutley, NJ). AP5 was dissolved in a minimum quantity of $1 \mathrm{~N} \mathrm{NaOH}$, to which sterile water was added. All other drugs were dissolved in sterile water. Doses of PCP are expressed as the free base; doses of all other drugs are expressed in the forms described above.

\section{Results}

PCP $(1 \mathrm{mg} / \mathrm{kg})$ acquired discriminative control over responding in all pigeons; the geometric mean of the number of sessions to criterion (GM-STC) was 28.9. All five pigeons for which the training dose was decreased to $0.56 \mathrm{mg} / \mathrm{kg}$ PCP met the discrimination criterion at a GM-STC value of 8.1. Four out of these five pigeons reached criterion at a training dose that was decreased further to $0.32 \mathrm{mg} / \mathrm{kg}$ (GM-STC $=40.1$ ); one pigeon failed to meet the criterion within 100 sessions and was thereupon excluded from the study.

The accuracy of the post-criterion discrimination performance was not significantly different between the three pigeons that were trained with $1.0 \mathrm{mg} / \mathrm{kg}$ PCP and the four pigeons that were trained with $0.32 \mathrm{mg} / \mathrm{kg} \mathrm{PCP}[F(1,5)=$ $0.86]$, but was significantly higher during saline sessions than during drug sessions $[F(1,5)=13.43, P<0.02]$; the mean percentage of correct key selections $( \pm 1$ SEM) was $95 \pm 2$ during saline sessions and was $84 \pm 3$ during drug sessions. This effect of type of training session (drug or saline) was not significantly different at the two training dose levels $[F(1,5)=0.03]$.

At each training dose, PCP exerted dose-dependent effects on the percentage of PCP-key selections (Fig. 1). The log dose-key selection data obtained at each training dose could be fitted adequately by straight lines; the correlation coefficients $(r)$ ranged from 0.89 to 1.0 . The slopes of these lines were not significantly different $(P>0.05)$; the overall slope value, indicating the amount by which the percentage of drug-key selections increased per $1 \log$ unit increase of dose, was 143 . The training dose significantly affected the geometric mean threshold dose (GM-TD) $[F(2,6)=15.66$, $P<0.001]$; GM-TD was $0.75 \mathrm{mg} / \mathrm{kg}$ at a training dose of $1 \mathrm{mg} / \mathrm{kg}$ and was significantly lower (i.e., $0.37 \mathrm{mg} / \mathrm{kg}$ ) at a training dose of $0.56 \mathrm{mg} / \mathrm{kg}(P<0.05)$. Further, GM-TD was $0.16 \mathrm{mg} / \mathrm{kg}$ at a training dose of $0.32 \mathrm{mg} / \mathrm{kg}$, a value that is significantly lower than the value obtained at a training dose of $0.56 \mathrm{mg} / \mathrm{kg}(P<0.01)$.Thus, reducing the training dose from 1.0 to $0.32 \mathrm{mg} / \mathrm{kg}$ produced a 4.8 -fold reduction of the geometric mean threshold dose, indicating that the potency of PCP increased about 5-fold. PCP did not significantly affect the mean key selection latency $[F(4,12)<$ $1.9, P>0.10]$, at the training doses used herein.

\section{\% PCP-KEY}

SELECTIONS

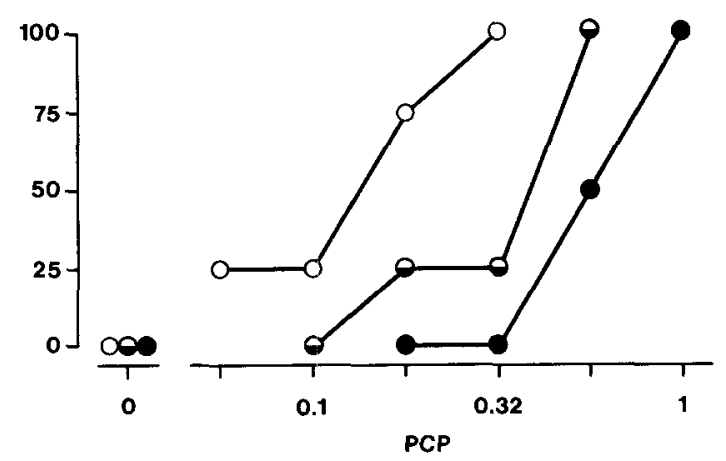

Fig. 1. Discriminative stimulus effects of PCP in pigeons $(n=3)$ trained to discriminate between IM injections of PCP and of saline. The training dose of $\mathrm{PCP}$ was lowered progressively from 1 to $0.32 \mathrm{mg} / \mathrm{kg}$ and a dose-effect curve was established at each training dose level, in pigeons $(n=4)$ that met the discrimination criterion at all training doses. Ordinate: percentage of PCP-key selections; abscissa: IM dose administered (mg per $\mathrm{kg}$ ). Training dose $\bullet-\bullet$ $1 \bullet-\odot 056 \circ-00.32$

AP5 and metaphit produced PCP-appropriate responding (Fig. 2), in all pigeons that were trained with $1 \mathrm{mg} / \mathrm{kg}$ $\mathrm{PCP}$ and in all pigeons that were trained with $0.32 \mathrm{mg} / \mathrm{kg}$ PCP. The dose-effect data obtained with PCP, AP5 and metaphit, at both training dose levels, could be fitted adequately (the value of $r$ ranged from 0.86 to 1.0 ) by straight lines, that did not deviate significantly from parallelism $(P>0.05$; overall slope value: 139$)$. Analysis of the logthreshold doses of PCP, AP5 and metaphit at both training doses showed a statistically significant effect of training dose $[F(1,5)=33.10, P<0.005]$, a significant effect of test drug $[F(2,10)=151.57, P<0.001]$ and a non-significant training dose $\times$ test drug interaction $[F(2,10)=0.13]$. PCP was significantly more potent than metaphit $(P<0.01)$ and than AP5 $(P<0.01)$. PCP was about 40 times more potent than metaphit and about 230 times more potent than AP5, irrespective of the training dose of PCP. Further, PCP, metaphit, and AP5 were about four times more potent in the group that was trained with $0.32 \mathrm{mg} / \mathrm{kg} \mathrm{PCP}$ than in the group that was trained with $1 \mathrm{mg} / \mathrm{kg}$ PCP.

However, the effects of metaphit and AP5 on key selection latency did not appear to vary as a function of the training dose of PCP. Both metaphit and AP5 induced $1 \mathrm{mg} / \mathrm{kg}$-PCP appropriate responding at doses that significantly increased the key-selection latency $(P<0.01$, in both cases). The geometric mean latency was increased from $10.9 \mathrm{~s}$ to $2105.4 \mathrm{~s}$ by $38 \mathrm{mg} / \mathrm{kg}$ metaphit and to $1871 \mathrm{~s}$ by $180 \mathrm{mg} / \mathrm{kg}$ AP5. Moreover, at these doses ataxia was evident in the pigeons upon their removal from the experimental chambers after the session had ended.

In pigeons that were trained with $0.32 \mathrm{mg} / \mathrm{kg} \mathrm{PCP}$, metaphit failed to significantly affect key-selection latency $[F(4,12)=0.67]$ and AP5 significantly increased key-selection latency only at a dose of $100 \mathrm{mg} / \mathrm{kg}(P<0.01)$. This dose of AP5 was higher than the dose that induced PCPappropriate responding in all animals (i.e., $56 \mathrm{mg} / \mathrm{kg}$ ). Further, ataxia did not occur at doses of metaphit and AP5 that induced $0.32 \mathrm{mg} / \mathrm{kg}-\mathrm{PCP}$ appropriate responding in all animals. Thus, it should be noted that metaphit and AP5 produced $\mathrm{PCP}$-appropriate responding at doses that pro- 

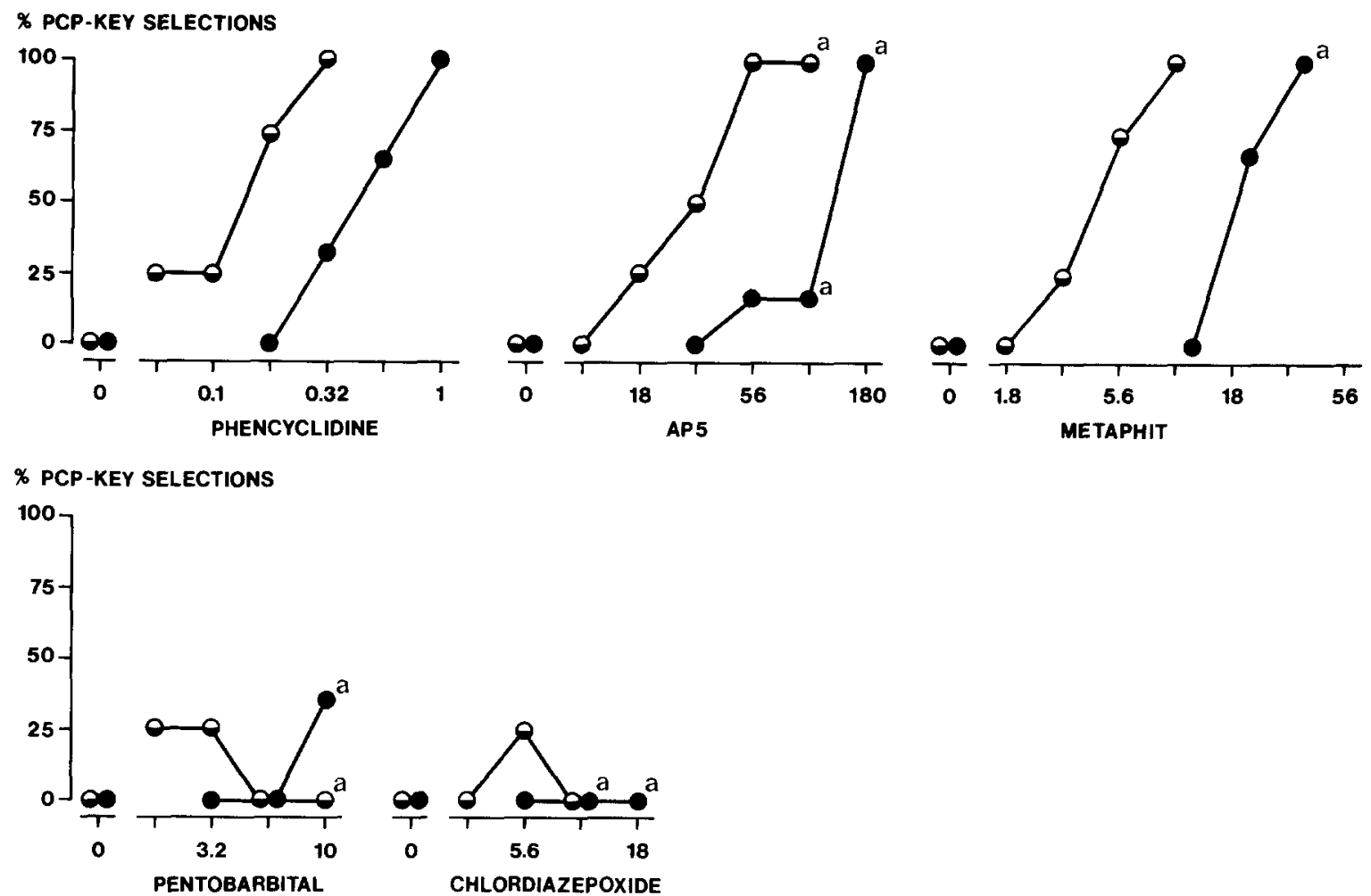

Fig. 2. Discriminative stimulus effects of PCP, AP5, metaphıt, pentobarbital and chlordiazepoxide in pigeons $(n=3)$ trained to discriminate between injections of $1 \mathrm{mg} / \mathrm{kg} \mathrm{PCP}$ and of saline, and in pigeons $(n=4)$ trained to discriminate between injections of $0.32 \mathrm{mg} / \mathrm{kg} \mathrm{PCP}$ and of saline. Data points that are marked with a "a" were obtained at doses that significantly increased the mean key-selection latency. Ordinates: percentage of PCP-key selections; abscissae: IM dose administered (mg per $\mathrm{kg}$ ). Dose-response curves of AP5 and of metaphit in pigeons that were trained with a dose of $1 \mathrm{mg} / \mathrm{kg}$ PCP are replotted from other sources (Koek et al. 1985, 1986b). $\bullet \mathrm{PCP}, 0.32 \mathrm{mg} / \mathrm{kg} \bullet \longrightarrow \mathrm{PCP}, 1.0 \mathrm{mg} / \mathrm{kg}$

duced neither direct effects on key selection latency nor ataxia.

Neither pentobarbital nor chlordiazepoxide produced PCP-appropriate responding in all animals, at both training doses of PCP (Fig. 2). Further, the maximum effect produced by these drugs, measured as the percentage of pigeons that selected the PCP key, was not significantly different in pigeons that were trained with $0.32 \mathrm{mg} / \mathrm{kg}$ PCP than in pigeons that were trained with $1 \mathrm{mg} / \mathrm{kg} \mathrm{PCP}$ (the value of chi-square with 1 degree of freedom equalled 0.06 for pentobarbital and $\mathbf{1 . 2 4}$ for chlordiazepoxide; $P>0.20$ in both cases). Pentobarbital $(10 \mathrm{mg} / \mathrm{kg})$ significantly increased key-selection latency from 8.9 to $51.3 \mathrm{~s}$ in the high training dose group $(P<0.05)$ and to $380.2 \mathrm{~s}$ in the low training dose group $(P<0.01) ; 18 \mathrm{mg} / \mathrm{kg}$ suppressed responding completely. Chlordiazepoxide significantly increased key-selection latency in both training dose groups: the latency was increased to $40.7 \mathrm{~s}$ by $10 \mathrm{mg} / \mathrm{kg}$ chlordiazepoxide $(P<0.05)$ and to $1047.1 \mathrm{~s}$ by $18 \mathrm{mg} / \mathrm{kg}(P<0.01)$ in the high training dose group. In the low training dose group, $10 \mathrm{mg} / \mathrm{kg}$ chlordiazepoxide increased the selection latency to $602.6 \mathrm{~s}(P<0.05)$; the animals failed to select either key during the $60 \mathrm{~min}$ session after $18 \mathrm{mg} / \mathrm{kg}$ chlordiazepoxide.

\section{Discussion}

The lowering of the training dose of PCP from 1 to $0.32 \mathrm{mg} /$ $\mathrm{kg}$ PCP shifted the generalization curve about 5-fold to the left, in a parallel manner (see also Beardsley et al. 1987). Further, neither the accuracy of the post-criterion discrimination performance nor the pharmacological specificity of the discrimination was significantly affected by the progressive lowering of the training dose. Thus, an assay of PCPlike discriminative stimulus effects was obtained that was more sensitive but neither less accurate nor less pharmacologically specific. AP5 and metaphit were found to substitute completely for $\mathrm{PCP}$, both when a high and when a progressively lowered training dose of PCP was used. Further, AP5 and metaphit substituted completely for $0.32 \mathrm{mg}$ / $\mathrm{kg} \mathrm{PCP}$ at doses that were about 4-fold lower than the doses of these drugs that substituted for $1 \mathrm{mg} / \mathrm{kg} \mathrm{PCP}$. At these lower doses, AP5 $(56 \mathrm{mg} / \mathrm{kg})$ and metaphit $(10 \mathrm{mg} / \mathrm{kg})$ neither increased the latency to select the PCP-appropriate key, nor produced ataxia. These results suggest that AP5 and metaphit may produce discriminative stimulus effects at doses that are at least 5-fold lower than the doses at which these drugs produce PCP-like catalepsy (catalepsy is induced in all subjects by $320 \mathrm{mg} / \mathrm{kg}$ AP5 and by $66 \mathrm{mg} /$ $\mathrm{kg}$ metaphit; Koek et al. 1985, 1986b). That these discriminative stimulus effects are indeed PCP-like is suggested by the finding that the pharmacological specificity of the PCP discrimination did not appear to be diminished by the progressive lowering of the training dose. Thus, the findings of the present study suggest that both AP5 and metaphit may produce PCP-like effects at doses that are substantially lower than the cataleptic dose and that do not produce directly observable behavioral effects. 
In some drug classes, low training doses may be associated with a lower degree of pharmacological specificity (e.g., Overton 1984). Because of the substantial amount of cross-generalization between PCP and pentobarbital (e.g., Overton 1975; McMillan and Wenger 1983), the use of pentobarbital as a test drug in the present study would appear to offer a strong test of a possible reduction of the pharmacological specificity of the PCP discrimination. However, evidence for such a reduction was not obtained. Thus, a lowering of the training dose of PCP does not necessarily produce a lowered specificity. The lowering of the training dose of PCP shifted the generalization curve in a parallel manner. It may be that a reduction of the pharmacological specificity will be obtained only when the generalization curve flattens as the training dose is lowered further.

In the present study, complete dose-effect curves or generalization gradients that were based on binary generalization data, were analyzed by performing analyses of variance on threshold-dose values. This method was sensitive to differences in the position of the dose-effect curves on the dose-axis; thus, it may provide an appropriate alternative to the method of Litchfield and Wilcoxon for the analysis of potency differences. For dose-effect curves that are based on binary generalization data, an entirely appropriate analysis of slope differences may still present a problem; tests of homogeneity of variances of threshold doses may be less sensitive than the methods described by Tallarida and Murray. However, the latter methods assume that the data samples obtained at different doses are independent. Evidence for a greater sensitivity of the methods described by Tallarida and Murray may be provided by the following hypothetical example: three linear dose-effect curves, that described the relation between log-dose and percentage of animals that selected the drug-appropriate key $(n=4)$, were constructed such that the dose that produced $0 \%$ drug-key selection and the doses that produced $100 \%$ drug-key selection were either $2 \log$-units (curve 1), $1 \log$-unit (curve 2), or $0.5 \log$-unit (curve 3) apart. Each curve was based on five data points $(0 \%, 25 \%, 50 \%, 75 \%$ and $100 \%$ drug key selection). Homogeneity tests of the variances of the log-threshold doses showed a significant difference between the data comprising curve 1 and curve $3[F(3,3)=15.88, P<$ 0.057 ; however, curve 2 was not significantly different from either curve 1 or curve $3(P>0.10)$. An analysis by means of the methods described by Tallarida and Murray showed the slope values of the three curves $(50,100$, and 200 , for curve 1,2 , and 3 , respectively) to be significantly different from one another (curve 1-curve 2: Student's $t=73.3, d f=$ 6, $P<0.001$; curve 1 - curve $3: t=101.5, d f=6, P<0.001$; curve 2 - curve $3: t=52.9, d f=6, P<0.001$ ).

NMDA antagonists have been proposed as having therapeutic potential as anticonvulsants (e.g., Meldrum 1985) and as anxiolytics (Bennett et al. 1985, 1986; Stephens et al. 1986). The present study offers further evidence of PCP-like behavioral effects of AP5, an NMDA antagonist. In addition, the results suggest that these PCP-like effects may not be restricted to sedating doses of AP5. Therefore, they make it even more relevant to evaluate PCP-like behavioral activity in trials of NMDA antagonists as potential anticonvulsants and anxiolytics.

Acknowledgements. We thank Richard Castello for technical assistance and Rebecca McLaughlin for manuscript preparation. This work was supported by a Constantijn and Christiaan Huygens Career Development Award to Wouter Koek, received from the Netherlands Organization for the Advancement of Pure Research (Z.W.O.), and by US Public Health Service Grant DA-00154.

\section{References}

Beardsley PM, Balster RL, Salay JM (1987) Separation of the response rate and discriminative stimulus effects of phencyclidine: training dose as a factor in phencyclidine-saline discrimination. J Pharmacol Exp Ther 241:159-165

Bennett DA, Corradi CL, Lehman CJ (1985) The excitatory amino acid receptor antagonist, 2-amino-7-phosphonoheptanoic acid (AP7) produces anticonflict activity. Soc Neurose (Abstr) $11: 106$

Bennett DA, Amrick CL (1986) 2-Amino-7-phosphonoheptanoic acid (AP7) produces discriminative stimuli and anticonflict effects similar to diazepam. Life Scr (in press)

Chen GM, Weston JK (1960) The analgesic and anesthetic effect of 1-(1-phenylcyclohexyl)piperidine $\mathrm{HCl}$ on the monkey. Anesth Analg 39:132-137

Chen GM, Ensor CR, Russell D, Bohner B (1959) The pharmacology of 1-(1-phenylcyclohexyl)piperidine $\mathrm{HCl}$. J Pharmacol Exp Ther 127:241-250

Colpaert FC (1986) Drug discrimination: methods of manipulation, measurement and analysis. In: Bozarth MA (ed) Methods of assessing the reinforcing properties of abused drugs (in press)

Colpaert FC, Niemegeers CJE, Janssen PAJ (1980) Factors regulating drug cue sensitivity: the effect of training dose in fentanylsaline discrimination. Neuropharmacology 19:705-713

Contreras PC, Johnson S, Freedman R, Hoffer B, Olsen K, Rafferty MF, Lessor RA, Rice KC, Jacobson AE, O`Donohue TL (1986) Metaphit, an acylating ligand for phencyclidine receptors: characterization of in vivo actions in the rat. J Pharmacol Exp Ther 238:1101-1107

Cook L, Davidson AB (1973) Effects of behaviorally active drugs in a conflict-punishment procedure in rats. In: Garattini $S$, Mussinı E, Randall LO (eds) The benzodiazepines. Raven, New York, pp 327-345

Domino EF, Luby ED (1981) Abnormal mental states induced by phencyclidine as a model of schizophrenia. In: EF Domino (ed) PCP (phencyclidine): historical and current perspectives. NPP Books, Ann Arbor, pp 401-418

Everitt BS (1977) The analysis of contingency tables. Chapman and Hall, London

Fagg GE, Foster AC, Ganong AH (1986) Excitatory amino acid synaptic mechanisns and neurological function. TIPS $7: 357-363$

Herling S, Coale EH Jr, Hein DW, Winger G, Woods JH (1981) Similarity of the discriminative stimulus effects of ketamine, cyclazocine, and dextrorphan in the pigeon. Psychopharmacology 73:286-291

Koek W, Head R, Holsztynska EJ, Woods JH, Domino EF, Jacobson AE, Rafferty MF, Rice KC, Lessor RA (1985) Effects of metaphit, a proposed phencyclidine receptor acylator, on catalepsy in pigeons. J Pharmacol Exp Ther 234:648-653

Koek W, Kleer E, Mudar PJ, Woods JH (1986a) Phencyclidıne-lıke catalepsy induced by the excitatory amino acid antagonist DL-2amino-5-phosphonovalerate. Behav Brain Res 19:257-259

Koek W, Woods JH, Ornstein P (1986 b) Phencyclidine-like behavioral effects in pigeons induced by systemic administration of the excitatory amino acid antagonist, 2-amino-5-phosphonovalerate. Life Sci 39:973-978

Koek W. Woods JH, Jacobson AE, Rice KC, Lessor RA (1986c) Metaphit, a proposed phencyclidine receptor acylator: phencyclidine-like behavioral effects and evidence of absence of antagonist activity in pigeons and in rhesus monkeys. J Pharmacol Exp Ther 237:386-392

Koek W, Woods JH, Ornstein P (1987) A simple and rapid method for assessing similarities among directly observable behavioral 
effects of drugs : PCP-like effects of 2-amino-5-phosphonovalerate in rats. Psychopharmacology $91: 297-304$

Leander JD (1982) Comparison of phencyclidine, etoxadrol and dexoxadrol in the pigeon. Subst Alcohol Actions Misuse $2: 197-203$

Litchfield JT, Wilcoxon FJ (1949) A simplified method of evaluating dose-effect experiments. J Pharmacol Exp Ther 96:99-113

McMillan DE (1982) Generalization of the discriminative stimulus properties of phencyclidine to other drugs in the pigeon using color tracking under second order schedules. Psychopharmacology $78: 131-134$

McMillan DE, Wenger GR (1983) Effects of barbiturates and other sedative hypnotics in pigeons trained to discriminate phencyclidine from saline. J Exp Anal Behav 40:133-142

Meldrum B (1985) Possible therapeutic applications of antagonists of excitatory amino acid neurotransmitters. Clin Sci 68:113-122

Overton DA (1974) Experimental methods for the study of statedependent learning. Fed Proc 33:1800-1813

Overton DA (1975) A comparison of the discriminable CNS effects of ketamine, phencyclidine and pentobarbital. Arch Int Pharmacodyn Ther 215:180-189

Overton DA (1984) State dependent learning and drug discriminations. In: Iversen LL, Iversen SD, Snyder SH (eds) Handbook of psychopharmacology, vol 18. Plenum, New York, pp 59-127

Rafferty MF, Mattson M, Jacobson AE, Rice KC (1985) A specific acylating agent for the $[3 \mathrm{H}]$ phencyclidine receptors in rat brain. FEBS Lett 181:318-322

Robbins TW (1977) A critique of the methods available for the measurement of spontaneous motor activity. In: Iversen LL, Iversen SD, Snyder SH (eds) Handbook of psychopharmacology, vol 7. Plenum, New York, pp 37-82

Stephens DN, Meldrum BS, Weidmann R, Schneider C, Grutzner $M$ (1986) Does the excitatory amino acid receptor antagonist 2-APH exhibit anxiolytic activity? Psychopharmacology 90:166-169

Stolerman IP, D'Mello GD (1981) Role of training conditions in discrimination of central nervous system stimulants in rats. Psychopharmacology 73:295-303

Tallarida RJ, Murray RB (1981) Manual of pharmacologic calculations. Springer, New York Berlin He1delberg

Watkins JC, Evans RH (1981) Excitatory amino acid transmitters. Annu Rev Pharmacol Toxicol 21:165-204

Winer BJ (1971) Statistical principles in experimental design, 2nd edn. McGraw-Hill, New York

Woods JH, Koek W, Ornstein P (1987) A prelıminary study of PCP-like behavioral effects of 2-amino-5-phosphonovalerate in rhesus monkeys. In: Hicks TP, Lodge D, McLellan H (eds) Excitatory amino acid transmission. Liss, New York, pp 205212

Received December 23, 1986 / Final version May 6, 1987 